\title{
Antimicrobial Activity of Biogenic Hop-Based Silver Nanoparticles for Application in Sugar and Alcohol Industries
}

\author{
Thais Castro Borsaria, \\ Tais Germano-Costa ${ }^{a}$, Natalia Bilesky-Jose ${ }^{a}$, \\ Leonardo F. Fraceto ${ }^{b}$ and Renata de Lima*a \\ ${ }^{a}$ Laboratory of Bioactivity Assessment \\ and Toxicology of Nanomaterials \\ University of Sorocaba \\ km 92 Rodovia Raposo Tavares, Sorocaba, \\ São Paulo, 18023-000, Brazil \\ ${ }^{b}$ Laboratory of Environmental Nanotechnology \\ São Paulo State University (UNESP) \\ 511 Avenida Três de março, Sorocaba, São Paulo, 18087-180, Brazil
}

One of the largest problems in the sugar and alcohol industry is the presence of unwanted bacteria, which leads to a decrease in alcohol production. This work presents a possible way to control these undesirable bacteria using silver biogenic nanoparticles synthesized from hops. The research was aimed at synthesizing nanoparticles and evaluating their physical and chemical characteristics, antimicrobial activity and cytotoxic potential. Silver nanoparticles were synthesized using Humulus lupulus L. extract and silver nitrate solution $\left(10^{-3} \mathrm{M}\right)$. To evaluate the size and polydispersity, the dynamic light scattering (DLS) technique was used. The zeta potential and concentration of nanoparticles were assessed by microelectrophoresis and the nanoparticle tracing (NTA) technique, respectively. The analysis of the antimicrobial activity was performed by the disc diffusion test and by determining the minimum inhibitory concentration (MIC) against gram-positive bacteria. Cytotoxicity was assessed by the mitochondrial activity assay (MTT). The biogenic nanoparticles were shown to have bactericidal activity and the appropriate characteristics. Regarding the activity, the results showed that the nanoparticles obtained at pH 7 (with 5\% hop flower extract) inhibited all tested bacteria at concentrations of 2.1 to $4.3 \times 10^{9} \mathrm{NP} / \mathrm{mL}$, and the nanoparticles obtained at $\mathrm{pH} 8$ (with $20 \%$ hop flower extract) inhibited the tested bacteria at concentrations of 4.8 to $6.0 \times 10^{9} \mathrm{NPs} / \mathrm{mL}$, which means that the former presented higher potential bactericidal activity. Regarding cytotoxicity, nanoparticles of

(C) Siberian Federal University. All rights reserved

This work is licensed under a Creative Commons Attribution-NonCommercial 4.0 International License (CC BY-NC 4.0).

* Corresponding author E-mail address: renata.lima@prof.uniso.br ORCID: 0000-0002-6800-9787 (Germano-Costa T.); 0000-0001-9301-9090 (Bilesky-Jose N.); 0000-0001-8712-1144 (de Lima R.); 0000-0002-2827-2038 (Fraceto L.F.) 
both types showed a low cell death index, and the cell viability was above 70\%. Hops served as an effective stabilizing and reducing agent. The nanoparticles were effective in bacterial control and did not show cytotoxicity.

Keywords: gram-positive bacteria, biogenic synthesis, Humulus lupulus.

Citation: Borsari T.C., Germano-Costa T., Bilesky-Jose N., Fraceto L.F., de Lima R. Antimicrobial activity of biogenic hop-based silver nanoparticles for application in sugar and alcohol industries. J. Sib. Fed. Univ. Biol., 2019, 12(3), $277-286$. DOI: $10.17516 / 1997-1389-0302$.

\title{
Антимикробная активность \\ биогенных наночастиц серебра, \\ полученных с использованием экстракта хмеля, \\ для применения в сахарной
}

и алкогольной промышленности

\author{
Т.К. Борсари ${ }^{\text {a }, ~ Т . ~ Г е р м а н о-К о с т а ~}{ }^{a}$, \\ Н. Билески-Жозе ${ }^{a}$, Л.Ф. Фрасето ${ }^{\sigma}$, Р. де Лима ${ }^{a}$ \\ а Лаборатория оценки биологической активности \\ и токсикологии наноматериалов \\ Университет Сорокаба \\ Бразилия, 18023-000, Сан-Паулу, Сорокаба, \\ Родовия Рапосо Таварес, км 92 \\ ${ }^{6}$ Лаборатория экологических нанотехнологий \\ Государственный университет Сан-Паулу \\ Бразилия, 18087-180, Сан-Паулу, Сорокаба, \\ Авенида Трес де Мари, 511
}

Одной из наибольших проблем в сахарной и спиртовой промышленности является присутствие нежелательныхбактерий, приводящеекуменьшению продукиииалкоголя. Вработепредставлен возможный способ борьбы с этими нежелательными бактериями с использованием биогенных наночастии серебра. Исследование включало синтез наночастии, оценку их физико-химических характеристик, антимикробной активности и циитотоксического потенциала. Наночастицы серебра синтезировали с применением экстракта Huтulus lupulus L. u pacтвора нитрата серебра $\left(10^{-3} \mathrm{M}\right)$. Для оценки размера и полидисперсности наночастии был использован метод динамического рассеяния света (DLS); их дзета-потенциал и концентрацию измеряли c помощью микроэлектрофореза и отслеживания наночастии (NTA), соответственно. Анализ антимикробной активности проводили с помощью диско-диффузионного метода и определения минимальной ингибирующей конщентрации на грамположительных бактериях. Цитотоксичность установили методом оценки митохондриальной активности (МTT). 
Биогенные наночастицы обладали бактерицидной активностью; наночастицы, полученные при рН 7 (с 5\%-ным экстрактом иветков хмеля), были более активными и ингибировали все бактерии при концентрации от 2,1 до 4,3 $\times 10^{9}$ наночастии (нч) на мл; наночастицы, полученные при рН 8 (с 20\%-ным экстрактом иветков хмеля), ингибировали бактерии при концентрации от 4,8 до 7,2 × $10^{9}$ нч/мл. Относительно циттотоксичности оба типа наночастиц показали низкий индекс гибели клеток, жизнеспособность которых была выме 70 \%. Хмель служил эффективным стабилизирующим и восстанавливающим агентом при получении наночастиц. Наночастицы были эффективны для подавления бактерий, не проявляя циитотоксичности.

Ключевые слова: грамположительные бактерии, биогенный синтез, Hитиlus lupulus.

\section{Introduction}

For ethanol production, sugar and alcohol industries employ a process called alcoholic fermentation, where yeasts, mainly Saccharomyces cerevisiae Meyen ex E.C. Hansen, convert the sugars (sucrose) present in the substrate into ethanol and carbon dioxide. The propagation of undesirable bacteria is the main problem in ethanol production. These bacteria deplete the sucrose available for the desired fermentation process and produce large amounts of lactic acid, which results in a lower yield of alcohol (Skinner, Leathers, 2004). In addition, bacterial contamination leads to sugar cane deterioration, the inhibition of yeast growth and yeast death, an increase in flocculation, a decrease in biomass production during fermentation and an increase in undesired products. In terms of the operation process parameters, bacterial contamination can increase the fermentation time, increase the amount of acid required to treat the yeast and cause an increase in unfermented sugar content (Beckner et al., 2011; Prado, 2014).

Contaminating microorganisms can originate from the soil microbiota and sugar cane, where they are transported by water, through roots, stems and leaves, and by particles carried by the air (Naves et al., 2010). The most intensive propagation of microorganisms occurs during the fermentation process because the raw materials used in fermentation processes are a main source of contaminating microorganisms. Contamination in the sugar and alcohol industries is caused by gram-positive bacteria of the genera Acetobacter, Lactobacillus, Bacillus, Clostridium, Enterobacter, Leuconostoc and Streptococcus (Gallo, 1990; Rosales, 1989). Some of these bacteria easily adapt to the conditions of high temperatures, high alcohol content and low $\mathrm{pH}$ that occur in industrial alcoholic processes and grow rapidly, which was shown for lactic bacteria by Narendranath et al. (1997).

The main method used by the sugar and alcohol industries to control bacterial contamination is the application of conventional antibiotics that inhibit growth and kill specific microorganisms. However, continuous and indiscriminate use of antibiotics by industries can cause the bacteria present during the fermentation process to become more resistant to antibiotics due to natural selection (Skinner, Leathers, 2004).

The synthesis of metallic nanoparticles has attracted a number of researchers because nanometric particles show different physicochemical characteristics compared to larger-sized particles (Mody et al., 2010). This type of synthesis occurs by the reduction of metal ions and can be carried out by chemical, physical or biological methods. In chemical and physical synthesis, various chemical substances 
are used as reducing and stabilizing agents that can be toxic to the environment and human health. Biogenic synthesis is a new approach in nanobiotechnology, where extracts from living organisms, such as plants, bacteria and fungi, are used as reducing and stabilizing agents. These technologies exclude the occurrence of toxic residues and can be considered sustainable alternative practices that are environmentally friendly and economically viable (Iravani et al., 2014; Prabhu, Poulose, 2012).

Different metals can be used for nanoparticle biosynthesis; among them, silver is the most widely used metal due to the antimicrobial potential of $\mathrm{Ag}^{+}$ions (Ray et al., 2009). The bioreduction of silver ions $\left(\mathrm{Ag}^{+}\right)$and stabilization of silver nanoparticles are performed by a combination of primary and secondary metabolites present in plant extracts. Nanoparticle biosynthesis method is cost-effective and economically suitable for large-scale production (Mubarakali et al., 2011; Vijayakumar et al., 2013).

The hop plant (Humulus lupulus L.) is a climbing plant of European origin that belongs to the family Cannabaceae and the genus Humulus. In addition, $H$. lupulus is widely used in the production of beer to provide bitterness and scent. It also possesses antimicrobial potential that contributes to the preservation of beer (Zanoli, Zavatti, 2008).

In addition to brewing, hops have several beneficial medicinal applications, including their use as a source of phytoestrogen, a sedative for sleep disorders and an antimicrobial agent (Chadwick et al., 2006; Leite et al., 2013; Schiller et al., 2006). Concerning the antimicrobial effects of hops, the alpha and beta acids present in hops are responsible for inhibiting the growth of microorganisms because they interfere with the transport of metabolites in the cell membrane and alter the intracellular $\mathrm{pH}$, causing nutritional insufficiency (Behr, Vogel, 2010). Hops are effective against gram-positive bacteria, such as some species of Micrococci, Staphylococci, Mycobacteria and Streptomycetes, but have no effect on gram-negative bacteria (Muthaiyan et al., 2011; Zanoli, Zavatti, 2008).

The aim of this work was to synthesize biogenic silver nanoparticles with bactericidal activity using $H$. lupulus extract and to evaluate their physical and chemical characteristics, antimicrobial activity and toxicity.

\section{Materials and methods}

\section{Materials}

For the cell viability analyses, the 3T3 (Mus musculus embryonic fibroblast), HaCaT (human keratinocyte) and V79 (Chinese hamster lung fibroblast) lines were obtained from the Cell Bank of Rio de Janeiro. For the microbiological analyses, Kocuria rhizophila, Clostridium perfringens, Clostridium sporogenes, Bacillus cereus, and Micrococcus luteus were provided by Cefar.

\section{Preparation of hop flower extract}

To prepare the extract, hop flowers (from Heineken Brasil) were chopped, macerated, transferred to a beaker and mixed with $100 \mathrm{~mL}$ of ultrapure water. The suspension was stirred at $60^{\circ} \mathrm{C}$ for 30 minutes. In this way, a suspension of hops at $0.2 \mathrm{~g} / \mathrm{mL}$ was obtained. The hop suspension was filtered at $0.2 \mu \mathrm{m}$ and used at different concentrations for the synthesis of nanoparticles.

\section{Synthesis of silver nanoparticles}

Nanoparticle synthesis was based on the procedure described by Ahmed et al. (2016). Initially prepared silver nitrate solution $\left(10^{-3} \mathrm{M}\right)$ was added to the hop flowers extract $(0.2 \mathrm{~g} / \mathrm{mL})$ obtained as described above. Silver nanoparticles were prepared in two variations using the mixtures with the content of the hop 
flowers extract of 5 and $20 \%$ with $\mathrm{pH} 7$ and 8 , respectively. Hereafter, we will refer to these nanoparticles as $\mathrm{pH} 7(5 \%)$ nanoparticles and $\mathrm{pH}$ $8(20 \%)$ nanoparticles. The resulting suspensions were kept at room temperature under agitation in the dark until they acquired a brownish color, indicating the formation of nanoparticles.

\section{Physicochemical characterization of nanoparticles}

The size, polydispersion (PDI) and zeta potential of the nanoparticles were determined using ZetaSizer Nano ZS90 (Malvern) equipment. The size and PDI of the nanoparticles were measured using the dynamic light scattering (DLS) technique, and the zeta potential was measured by microelectrophoresis. The measurements were performed at a fixed angle of $90^{\circ}$ and a temperature of $25^{\circ} \mathrm{C}$. The concentration and size distribution were determined by the nanoparticle tracing analysis technique (NTA) using NanoSight LM14 equipment connected to a camera with preinstalled NanoSight v.2.3 software.

\section{Disc diffusion test}

The bacteria were inoculated in nutrient broth and incubated at $35^{\circ} \mathrm{C}$ for $24 \mathrm{~h}$, then diluted to $10^{8} \mathrm{CFU} / \mathrm{mL}$ and spread with a swab on plates containing nutrient agar. After 10 minutes, filter paper discs containing silver nanoparticles were placed on the plate and incubated at $37^{\circ} \mathrm{C}$ for $24 \mathrm{~h}$. As a control, a disc containing penicillinstreptomycin $0.1 \mathrm{U} / \mathrm{mL}-0.1 \mathrm{mg} / \mathrm{mL}$ solution was used.

\section{Minimum inhibitory concentration (MIC)}

To determine the minimum inhibitory concentration, the method of Palomino et al. (2002) was used. Bacterial strains were grown in nutrient broth for $24 \mathrm{~h}$. Then, the bacteria were diluted to a concentration of $5 \times 10^{6} \mathrm{CFU} / \mathrm{mL}$. To perform the assay, 96-well plates were used. Aliquots $(10 \mu \mathrm{l})$ of the bacterial suspensions were added to the wells in addition to the nanoparticles in decreasing concentrations and supplemented with nutrient broth to a final volume of $90 \mu \mathrm{l}$. The plates were incubated at $37^{\circ} \mathrm{C}$ for $24 \mathrm{~h}$. Then, $10 \mu \mathrm{l}$ of resazurin $(6.75 \mathrm{mg} / \mathrm{mL})$ was added to each well. The plates were incubated for another $24 \mathrm{~h}$, and an analysis of the results was performed based on the observed color change.

\section{Mitochondrial activity assay (MTT)}

Cells were plated at a density of $5.0 \times 10^{4}$ cells/ $\mathrm{mL}$ and incubated at $37^{\circ} \mathrm{C}$ for adhesion. After $24 \mathrm{~h}$, the cells were exposed to a series of treatments with nanoparticles in decreasing concentrations (between $7.56 \times 10^{2}$ and $7.56 \times 10^{10} \mathrm{NPs} / \mathrm{mL}$ ) for $24 \mathrm{~h}$. After the treatment, the culture was washed with PBS followed by the addition of $100 \mu \mathrm{L}$ of tetrazolium bromide solution at $0.5 \mathrm{mg} / \mathrm{mL}$. The plates were incubated for $3 \mathrm{~h}$ at $37^{\circ} \mathrm{C}$ and $5 \% \mathrm{CO}_{2}$, the medium was removed and $100 \mu \mathrm{L}$ of DMSO was added. The readings were obtained using an ELISA microplate reader (Elx 800 Bio-Tek) at $570 \mathrm{~nm}$.

\section{Statistical analysis of results}

All tests were performed in triplicate, and statistical analyses were performed using ANOVA followed by Tukey's HSD post hoc test using the GraphPad Prism program (statistical significance of $p<0.05$ ).

\section{Results}

\section{Physicochemical characteristics}

The results from physicochemical analyses indicated that the nanoparticles synthesized from the hop extract had a size in the range of 90 to $140 \mathrm{~nm}$, with a polydispersity of less than 0.4 and a negative zeta potential of approximately $-30 \mathrm{mV}$ (Table 1). 


\section{Disc diffusion test}

In the disc diffusion test, the synthesized nanoparticles showed antimicrobial activity against all bacteria strains tested (Table 2), indicating their good potential for this application.

\section{Minimum inhibitory concentration} (MIC)

The results showed that the $\mathrm{pH} 7(5 \%)$ nanoparticles were more efficient than the $\mathrm{pH} 8$ (20\%) nanoparticles (Table 3), indicating that the pH 7 (5\%) nanoparticles had a higher bactericidal potential.

The results also showed that the different bacteria tested exhibited different responses, with $C$. sporogenes and B. cereus being the most sensitive to the nanoparticles.

\section{Cytotoxicity analysis by MTT}

The values of the cell viability indexes were above $70 \%$ in relation to the two nanoparticle types, and a 50\% inhibition (IC50) was not observed in any of the cell lines tested (Fig. 1).

\section{Discussion}

The change in the color of the hop flower extract and silver nitrate solution mixture to a brownish color is normally indicative of the biogenic synthesis of silver nanoparticles in the suspension. This color change is due to the reduction of $\mathrm{Ag}^{+}$ions to $\mathrm{Ag}^{0}$ mediated by the metabolites present in the extract. At the end of the process, nanoparticles of a new type are formed. These nanoparticles are coated with biomolecules that come from the extract (Ahmad et al., 2011) and are of a larger size, approximately

Table 1. Size, polydispersity, zeta potential and concentration of silver biogenic nanoparticles from the hop extract

\begin{tabular}{|c|c|c|c|c|c|}
\hline \multirow{2}{*}{ NPs } & \multicolumn{3}{|c|}{ DLS } & \multicolumn{2}{c|}{ NTA } \\
\cline { 2 - 6 } & $\begin{array}{c}\text { Diameter } \\
(\mathrm{nm})\end{array}$ & Polydispersity & $\begin{array}{c}\text { Zeta potential } \\
(\mathrm{mV})\end{array}$ & $\begin{array}{c}\text { Diameter } \\
(\mathrm{nm})\end{array}$ & $\begin{array}{c}\text { Concentration } \\
(\mathrm{NPs} / \mathrm{mL})\end{array}$ \\
\hline $\mathrm{pH} \mathrm{7} \mathrm{(5 \% )}$ & $108.83 \pm 0.89$ & $0.27 \pm 0.00$ & $-30.83 \pm 4.46$ & $136.80 \pm 9.00$ & $2.10 \times 10^{11}$ \\
\hline $\mathrm{pH} 8(20 \%)$ & $102.18 \pm 3.21$ & $0.38 \pm 0.06$ & $-34.73 \pm 1.16$ & $91.00 \pm 3.80$ & $2.40 \times 10^{11}$ \\
\hline
\end{tabular}

Table 2. Diameter of inhibition halos in the disc diffusion test with gram-positive bacteria

\begin{tabular}{|c|c|c|c|c|c|}
\hline \multirow{2}{*}{ NPs } & \multicolumn{5}{|c|}{ Inhibition halos (mm) } \\
\cline { 2 - 6 } & K. rhizophila & C. perfringens & C. sporogenes & B. cereus & M. luteus \\
\hline $\mathrm{pH} 7(5 \%)$ & 8.5 & 11.0 & 9.0 & 9.5 & 10.5 \\
\hline $\mathrm{pH} 8(20 \%)$ & 8.0 & 10.5 & 9.5 & 9.0 & 11.0 \\
\hline
\end{tabular}

Table 3. Minimum inhibitory concentration (MIC) of biogenic silver nanoparticles from the hop extract

\begin{tabular}{|c|c|c|c|c|c|}
\hline \multirow{2}{*}{ NPs } & \multicolumn{5}{|c|}{ Minimum inhibitory concentration (NPs/mL) } \\
\cline { 2 - 6 } & K. rhizophila & C. perfringens & C. sporogenes & B. cereus & M. luteus \\
\hline $\mathrm{pH} 7(5 \%)$ & $4.3 \times 10^{9}$ & $4.3 \times 10^{9}$ & $2.1 \times 10^{9}$ & $2.1 \times 10^{9}$ & $4.3 \times 10^{9}$ \\
\hline $\mathrm{pH} 8(20 \%)$ & $6.0 \times 10^{9}$ & $4.8 \times 10^{9}$ & $4.8 \times 10^{9}$ & $4.8 \times 10^{9}$ & $4.8 \times 10^{9}$ \\
\hline
\end{tabular}



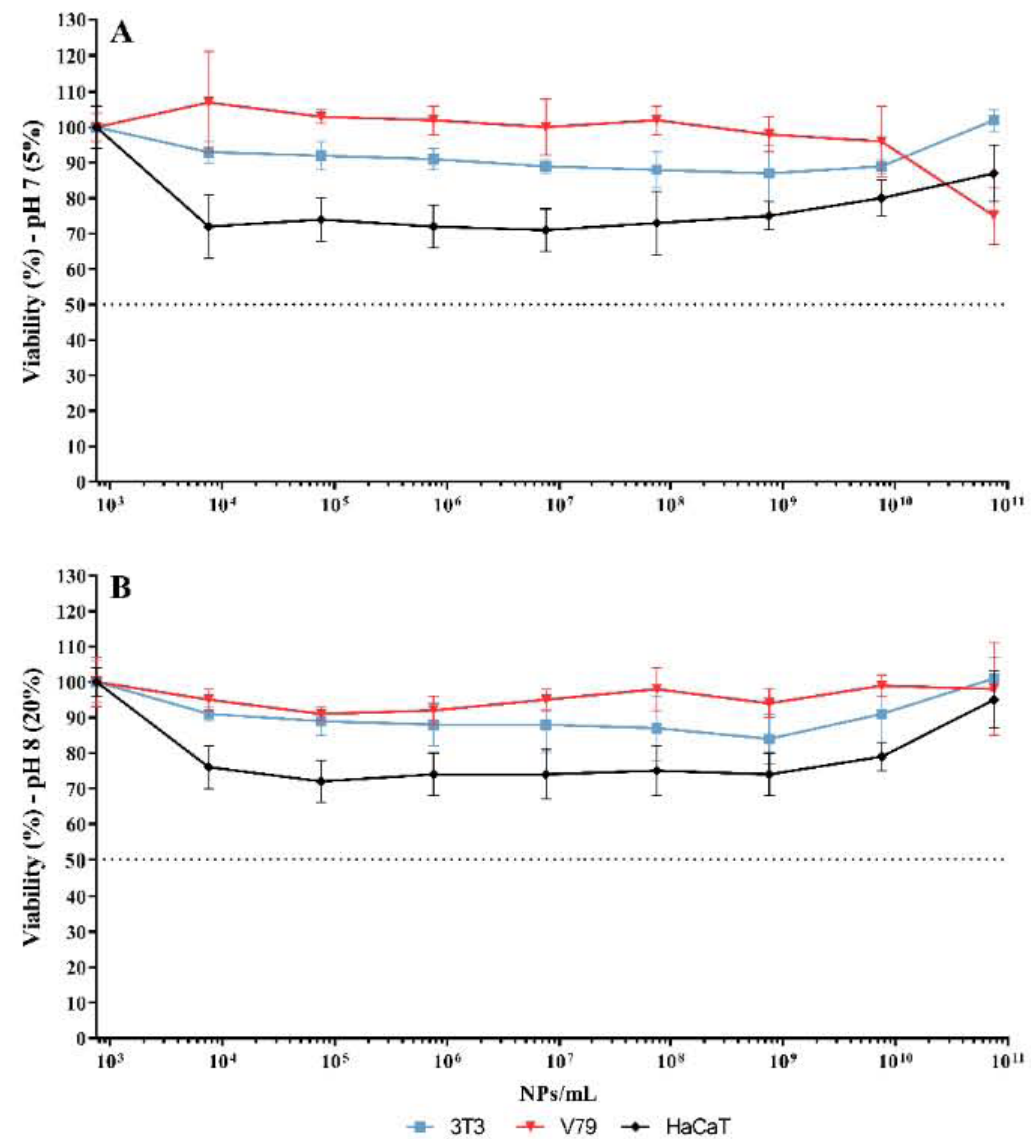

Fig. 1. Results of the cytotoxicity analysis of the nanoparticles by MTT in the 3T3, V79 and HaCaT cell lines. A: pH 7 (5\%) nanoparticles; B: pH 8 (20\%) nanoparticles

more than $100 \mathrm{~nm}$, and with a negative zeta potential (Mohammed et al., 2018; Singh et al., 2015). Kokila et al. (2016) showed that silver nanoparticles synthesized from Carica papaya bark extract had great stability due to their coating. The authors maintained that the negative value of the zeta potential may occur because of this coating, which also leads to greater stability of the nanoparticles.

Some studies have shown that in biogenic nanoparticles, the size and shape influence the antimicrobial activity. In these nanoparticles, the smaller nanoparticles show greater activity due to their larger surface area and more active interaction with bacteria (Kumar et al., 2016). Different results were observed in this work, where the $\mathrm{pH} 7(5 \%)$ nanoparticles with a larger diameter showed higher activity than the pH 8 (20\%) nanoparticles. The antimicrobial activity of pure hop extract and xanthohumol, a constituent of hops, on Staphylococcus aureus showed MIC values of 0.031 and $0.015 \mathrm{mg} / \mathrm{mL}$ for pure extract and xanthohumol, respectively (Rozalski et al., 2013). Silver nanoparticles from Carica papaya synthesized by Kokila et al. (2016) showed antimicrobial activity against gram-positive bacteria (S. aureus and Bacillus subtilis), as determined by the disc diffusion test with inhibition halos of 10 and $12 \mathrm{~mm}$, respectively. Ahmad et al. (2017) determined that the antibacterial effect of the biogenic silver nanoparticles from Coptis chinensis occurs 
due to their interaction with the bacterial cell membrane, causing damage followed by cell death. Other studies have observed that the antibacterial effect is a result of the production of reactive oxygen species (ROS), which in turn affect the DNA (Choi, Hu, 2008; Duran et al., 2010; Prabhu, Poulose, 2012; Rai et al., 2012; Kon, Rai, 2013).

The concentration of nanoparticles required to inhibit bacterial growth did not show cytotoxicity in any of the cell lines analyzed. The data on the cytotoxicity of biogenic nanoparticles found in the literature are still equivocal. Silver nanoparticles synthesized from Acalypha indica were evaluated in breast cancer cells (MDA-MB-231) by the MTT assay at various concentrations $(1,10$, 50 and $100 \mu \mathrm{g} / \mathrm{mL}$ ), and cytotoxicity was not observed at any concentrations tested, with cell viability always above $60 \%$, even at the highest concentration tested (Krishnaraj et al., 2014). However, studies conducted by Khorrami et al. (2018) reported that silver nanoparticles from Juglans regia at $60 \mu \mathrm{g} / \mathrm{mL}$ presented $85 \%$ cell viability in normal areolar and subcutaneous adipose tissue from rats (L-929) and 30\% in breast cancer cells (MCF-7). Toxicity was also observed in the analyses performed by Rheder et al. (2018), where the $\mathrm{IC}_{50}$ of silver biogenic nanoparticles obtained from Althea officialis were $3.75 \times 10^{2}$ and $1.38 \times 10^{8} \mathrm{NPs} / \mathrm{mL}$ for tumoral (A549) and normal (V79) lung lines, respectively, and $2.78 \times 10^{6} \mathrm{NPs} /$ $\mathrm{mL}$ for uterine tumor cells (HeLa).

\section{Conclusion}

The research showed that it was possible to synthesize silver nanoparticles from hop extract. These nanoparticles were of adequate size, polydispersity, zeta potential, concentration and stability. Moreover, the results showed that the nanoparticles possess antibacterial potential against gram-positive bacteria but were not cytotoxic in the tested cell lines, which means that they are potentially a more sustainable, effective and economically viable alternative to be used for bacterial contamination control in sugar and alcohol industries.

\section{References}

Ahmad N., Sharma S., Singh V.N., Shamsi S.F., Fatma A., Mehta B.R. (2011) Biosynthesis of silver nanoparticles from Desmodium triflorum: a novel approach towards weed utilization. Biotechnology Research International, 2011: ID 454090

Ahmad A., Wei Y., Syed F., Tahir K., Rehman A.U., Khan A., Ullah S., Yuan Q. (2017) The effects of bacteria-nanoparticles interface on the antibacterial activity of green synthesized silver nanoparticles. Microbial Pathogenesis, 102: 133-142

Ahmed S., Ahmad M., Swami B.L., Ikram S. (2016) A review on plants extract mediated synthesis of silver nanoparticles for antimicrobial applications: A green expertise. Journal of Advanced Research, 7(1): $17-28$

Beckner M., Ivey M.L., Phister T.G. (2011) Microbial contamination of fuel ethanol fermentations. Letters in Applied Microbiology, 53(4): 387-394

Behr J., Vogel R.F. (2010) Mechanisms of hop inhibition include the transmembrane redox reaction. Applied and Environmental Microbiology, 76(1): 142-149

Chadwick L.R., Pauli G.F., Farnsworth N.R. (2006) The pharmacognosy of Humulus lupulus L. (hops) with an emphasis on estrogenic properties. Phytomedicine, 13(1-2): 119-131

Choi O., Hu Z. (2008) Size dependent and reactive oxygen species related nanosilver toxicity to nitrifying bacteria. Environmental Science \& Technology, 42(12): 4583-4588 
Duran N., Marcato P.D., De Conti R., Alves O.L., Costa F.T.M., Brocchi M. (2010) Potential use of silver nanoparticles on pathogenic bacteria, their toxicity and possible mechanisms of action. Journal of the Brazilian Chemical Society, 21(6): 949-959

Gallo C.R. (1990) Determination of the bacterial microbiota of must and fermentation dornas. Doctoral thesis. Faculty of Food Engineering, UNICAMP

Iravani S., Korbekandi H., Mirmohammadi S.V., Zolfaghari B. (2014) Synthesis of silver nanoparticles: chemical, physical and biological methods. Research in Pharmaceutical Sciences, 9(6), $385-406$

Khorrami S., Zarrabi A., Khaleghi M., Danaei M., Mozafari M.R. (2018) Selective cytotoxicity of green synthesized silver nanoparticles against the MCF-7 tumor cell line and their enhanced antioxidant and antimicrobial properties. International Journal of Nanomedicine, 13: 8013-8024

Kokila T., Ramesh P.S., Geetha D. (2016) Biosynthesis of AgNPs using Carica Papaya peel extract and evaluation of its antioxidant and antimicrobial activities. Ecotoxicology and Environmental Safety, 134: $467-473$

Kon K., Rai M. (2013) Metallic nanoparticles: mechanism of antibacterial action and influencing factors. Journal of Comparative Clinical Pathology Research, 2: 160-174

Krishnaraj C., Muthukumaran P., Ramachandran R., Balakumaran M.D., Kalaichelvan P.T. (2014) Acalypha indica Linn: biogenic synthesis of silver and gold nanoparticles and their cytotoxic effects against MDA-MB-231, human breast cancer cells. Biotechnology Reports, 4: 42-49

Kumar C.M.K., Yugandhar P., Savithramma N. (2016) Biological synthesis of silver nanoparticles from Adansonia digitata L. fruit pulp extract, characterization, and its antimicrobial properties. Journal of Intercultural Ethnopharmacology, 5(1): 79-85

Leite I.R., Faria J.R., Marquez L.D.S., Reis M.H.M., Resende M.M., Ribeiro E.J., Cardoso V.L. (2013) Evaluation of hop extract as a natural antibacterial agent in contaminated fuel ethanol fermentations. Fuel Processing Technology, 106: 611-618

Mody V.V., Siwale R., Singh A., Mody H.R. (2010) Introduction to metallic nanoparticles. Journal of Pharmacy \& BioAllied Sciences, 2(4): 282-289

Mohammed A.E., Al-Qahtani A., Al-Mutairi A., Al-Shamri B., Aabed K. (2018) Antibacterial and cytotoxic potential of biosynthesized silver nanoparticles by some plant extracts. Nanomaterials, 8: 382

MubarakAli D., Thajuddin N., Jeganathan K., Gunasekaran M. (2011) Plant extract mediated synthesis of silver and gold nanoparticles and its antibacterial activity against clinically isolated pathogens. Colloids and Surfaces B: Biointerfaces, 85(2): 360-365

Muthaiyan A., Limayem A., Ricke S.C. (2011) Antimicrobial strategies for limiting bacterial contaminants in fuel bioethanol fermentations. Progress in Energy and Combustion Science, 37(3): $351-370$

Narendranath N.V., Hynes S.H., Thomas K.C., Ingledew W.M. (1997) Effects of Lactobacilli on yeast-catalyzed ethanol fermentations. Applied and Environmental Microbiology, 63(11): 41584163

Naves R.F., Fernandes F.S., Pinto O.G., Naves P.L.F. (2010) Microbial contamination in the processing stages and its influence on the fermentative yield in an alcohol plant. Encyclopedia Biosphere [Enciclopédia Biosfera], 6(11): 1-16 (in Portuguese)

$$
-285-
$$


Palomino J.C., Martin A., Camacho M., Guerra H., Swings J., Portaels F. (2002) Resazurin microtiter assay plate: simple and inexpensive method for detection of drug resistance Mycobacterium tuberculosis. Antimicrobial Agents and Chemotherapy, 46(8): 2720-2722

Prabhu S., Poulose E.K. (2012) Silver nanoparticles: mechanism of antimicrobial action, synthesis, medical applications, and toxicity effects. International Nano Letters, 2: 32

Prado J.L. (2014) Use of conventional antibiotics and antimicrobials based on hops in the control of bacterial infection in alcoholic fermentation. Master's dissertation. Faculty of Agronomic Sciences of Botucatu, UNESP

Rai M., Yadav A., Gade A. (2009) Silver nanoparticles as a new generation of antimicrobials. Biotechnology Advances, 27(1): 76-83

Rai M.K., Deshmukh S.D., Ingle A.P., Gade A.K. (2012) Silver nanoparticles: the powerful nanoweapon against multidrug-resistant bacteria. Journal of Applied Microbiology, 112(5): 841-852

Rheder D.T., Guilger M., Bilesky-José N., Germano-Costa T., Pasquoto-Stigliani T., Gallep T., Grillo R., Carvalho C., Fraceto L.F., Lima R. (2018) Synthesis of biogenic silver nanoparticles using Althaea officinalis as reducing agent: evaluation of toxicity and ecotoxicity. Scientific Reports, 8: 12397

Rosales S.Y.R. (1989) Bacterial contaminants of ethanolic fermentation: isolation in differential medium, identification and evaluation of disinfectants. Doctoral thesis. Institute of Biosciences, UNESP

Rozalski M., Micota B., Sadowska B., Stochmal A., Jedrejek D., Wieckowska-Szakiel M., Rozalska B. (2013) Antiadherent and antibiofilm activity of Humulus lupulus L. derived products: new pharmacological properties. BioMed Research International, 2013: ID 101089

Schiller H., Forster A., Vonhoff C., Hegger M., Biller A., Winterhoff H. (2006) Sedating effects of Humulus lupulus L. extracts. Phytomedicine, 13(8): 535-541

Singh P., Kim Y.J., Singh H., Wang C., Hwang K.H., Farh M.E., Yang D.C. (2015) Biosynthesis, characterization, and antimicrobial applications of silver nanoparticles. International Journal of Nanomedicine, 10: 2567-2577

Skinner K.A., Leathers T.D. (2004) Bacterial contaminants of fuel ethanol production. Journal of Industrial Microbiology and Biotechnology, 31(9): 401-408

Vijayakumar M., Priya K., Nancy F.T., Noorlidah A., Ahmed A.B.A. (2013) Biosynthesis, characterisation and anti-bacterial effect of plant-mediated silver nanoparticles using Artemisia nilagirica. Industrial Crops and Products, 41: 235-240

Zanoli P., Zavatti M. (2008) Pharmacognostic and pharmacological profile of Humulus lupulus L. Journal of Ethnopharmacology, 116(3): 383-396 